\title{
COVID- 19 Vaccine Acceptance and its Predictors among College Students in Addis Ababa, Ethiopia, 2021: A Cross-Sectional Survey
}

\author{
Addisu Tadesse Sahile $\mathbb{D I}^{\prime}$, Betesida Mulugeta ${ }^{2}$, Semhal Hadush ${ }^{2}$, Endashew Mulate Fikre ${ }^{3}$ \\ 'Department of Public Health, Unity University, Addis Ababa, Ethiopia; ${ }^{2}$ Department of Public Health, Universal Medical and Business College, Addis \\ Ababa, Ethiopia; ${ }^{3}$ Department of HIVIAIDS Prevention, Addis Ababa City Health Bureau, Addis Ababa, Ethiopia
}

Correspondence: Addisu Tadesse Sahile, Email sahdis9I@gmail.com

Background: The coronavirus disease pandemic disrupted the normal social and economic activities of the people resulting in over 3 million deaths worldwide. Piece of literature depicted that predictors of vaccine acceptance are complex, multiple, and vary depending on the type of vaccine involved.

Objective: The study aimed at assessing the COVID-19 acceptance and its predictors among college students in Addis Ababa, Ethiopia, 2021

Methods: A multi-center-institutional-based cross-sectional study was conducted among 407 participants from three institutions in Addis Ababa selected based on a simple random sampling method from May 01 to July 30, 2021. A self-administered structured questionnaire was used for the collection of data, after which informed consent was obtained from all the included study participants. Descriptive statistics was used for the summarization of the data. Binary (bivariate and multivariate) logistic regression was applied for the identification predictors of vaccine acceptance with their respective $95 \%$ confidence interval and less than $5 \%$ p-value for the ascertainment of presence of association.

Results: The level of vaccine acceptance was 39.8\% (95\% CI: 35.0-44.7\%). Being male (AOR: $0.463,95 \%$ CI: $0.284-0.755, P<$ 0.001 ), living with children under the age of five (AOR: 2.295; 95\% CI: 1.416-3.721, $P<0.05$ ), living with an elderly (AOR: 1.609 , 95\% CI: $1.016-2.548, P<0.05$ ) and having had poor knowledge (AOR: $2.187,95 \%$ CI: $1.391-3.438, P<0.001$ ) were predictors significantly associated with an increased level of vaccine acceptance.

Conclusion and Recommendation: The level of vaccine acceptance among college students in Ethiopia was lower than necessary to achieve herd immunity. Sex, living with under-five children, and elderly, and knowledge were predictors of COVID-19 acceptance. Concerned bodies were suggested to work over the identified predictors of vaccine acceptance in the study settings.

Keywords: COVID-19, vaccine acceptance, predictors, college students

\section{Introduction}

The Coronavirus disease (COVID-19) pandemic disrupted the normal social and economic activities of the world ${ }^{1-5}$ and continued to havoc the globe. ${ }^{5}$ However, the African continent recorded fewer proportion of the COVID-19 infection; the disease caused over 3 million deaths worldwide. ${ }^{6}$

Numerous biologic and chemotherapeutic therapies such as convalescent plasma, tocilizumab, remdesivir and hydroxylchloroquine were applied for the treatment of COVID-19 patients ${ }^{7,8}$ with no conclusive evidence on its cure rate.

Nevertheless, it was a recent experience that most of the world practiced different public health measures, such as social distancing, lockdowns, respiratory hygiene, and hand hygiene for the prevention of COVID-19 disease, a little role was recorded $;^{9}$ rather, an effective vaccine as a standing solution was recommended during the crises. ${ }^{10,11}$

Vaccine hesitancy is a delay in acceptance or refusal of vaccine despite the availability of vaccination service. ${ }^{12}$ When safe and efficacious vaccines become available, governors could ensure a successful, large-scale uptake of COVID-19 vaccines to the attainment of community immunization. 
Existing studies on COVID-19 vaccine uptake revealed that a considerable proportion of people are careless of taking the vaccine. A representative study from 19 countries revealed, $71.5 \%$ were likely to take the COVID-19 vaccine. ${ }^{13}$ Perhaps; the evidence from 20 nations representative studies revealed the level of COVID-19 acceptance to be under $67 \%{ }^{14}$

The predictors of vaccine acceptance are complex, multiple, and vary depending on the type of vaccine involved. ${ }^{15-17}$ The level of trustworthiness of the source information determines the likelihood of vaccine acceptance, ${ }^{18}$ but trust in COVID-19 vaccination varies widely between different groups of people. ${ }^{19}$ It is reasonable to think more people trust vaccines, the more they will take the COVID-19 vaccine. However, the infodemic that inundated the world during the COVID-19 has changed vaccine acceptance,${ }^{20-23}$ - which directly shows that media sensationalism is linked to distrust in COVID and COVID-19 vaccines appear to have different predictors of acceptance than previous vaccine. ${ }^{24}$

To the best knowledge of the researchers, there was a limited evidence regarding the acceptance of COVID-19 vaccine by college students in Ethiopia. Informed by the above statement, this study assessed the acceptance and predictors of COVID-19 vaccine by college students in Addis Ababa, Ethiopia.

\section{Methods}

\section{Participants and Study Design}

A multi-center-institutional-based cross-sectional study design was conducted among 407 participants from the selected colleges in Addis Ababa from May 01 to July 30, 2021. The study received ethical approval from Universal Medical and Business College, a research review ethics committee and applied to the respective colleges. All the participants were provided written informed consent. The source population was all regular students of the selected colleges; namely, Universal Medical and Business College, Kea Med Medical and Business College, and Africa Health Science College. The study population was all the 407 participants from the selected colleges available during the study period. Students who registered in the stated colleges, available during data collection, and those free from severe medical conditions were included in the study. A simple random sampling technique was employed to select the participants after their lists were once identified from the registrar of the respective colleges.

The sample size was determined based on a single population proportion, with the premise that the magnitude of vaccine acceptance among college students taken at 50\%, since there was no prior study among the particular study group, $95 \%$ confidence interval 1.96 and 5\% margin of error. The final sample was 422 inclusive of a 10\% non-response rate.

Data were gathered with a pre-tested self-administered questionnaire. The questionnaire was developed by reviewing related pieces of literature ${ }^{25-29}$ then given to three senior researchers working in academic institutions, and their inputs were incorporated in the final tool.

\section{Definitions of Concepts}

The outcome variable (COVID-19 vaccine acceptance) was measured as yes and no question. ${ }^{1,27}$ Knowledge was measured as true and false questions and categorized as poor versus good knowledge based on median score after constructs forming knowledge were once computed.

\section{Statistical Analysis}

Descriptive statistics were used for the summarization of data. For the identification predictors of COVID-19 acceptance, binary (bi-variable and multivariable) logistic regression was used, with their respective 95\% Confidence Interval (CI) and p-value of less than 0.05 as a statistically significant level.

\section{Result}

\section{Socio-Demographic Characteristics}

Of 422 students approached, 407 respondents completed the questionnaire, with a response rate of $96 \%$. The majority $(82.8 \%)$ and $(68 \%)$ of the participants were single and females consecutively. The mean age of the participants was 21.9 years with a standard deviation of \pm 3.43 . Most (63.4\%) of the study participants had children living with them (Table 1). 
Table I Socio-Demographic Characteristics of Participants in Selected Colleges of Addis Ababa, Ethiopia, May, 2021

\begin{tabular}{|c|c|c|c|}
\hline Characteristics & Categories & Frequency & Percent \\
\hline \multirow[t]{2}{*}{ Sex } & Female & 277 & 68.1 \\
\hline & Male & 130 & 31.9 \\
\hline \multirow[t]{4}{*}{ Religion } & Orthodox & 265 & 65.1 \\
\hline & Protestant & 67 & 16.5 \\
\hline & Muslim & 57 & 14.0 \\
\hline & Catholic & 18 & 4.4 \\
\hline \multirow[t]{3}{*}{ Marital status } & Single & 337 & 82.8 \\
\hline & Married & 48 & 11.8 \\
\hline & Others * & 22 & 5.4 \\
\hline \multirow[t]{3}{*}{ Source of Income } & Family & 343 & 84.5 \\
\hline & Work & 44 & 10.8 \\
\hline & Others $* *$ & 20 & 4.9 \\
\hline \multirow[t]{6}{*}{ Department } & Pharmacy & 160 & 39.3 \\
\hline & Nursing & 118 & 29.0 \\
\hline & Health Officer & 86 & 21.1 \\
\hline & Medical doctor & 16 & 3.9 \\
\hline & Radiology & 16 & 3.9 \\
\hline & Lab. Technician & 11 & 2.7 \\
\hline \multirow[t]{5}{*}{ Academic year } & Freshman & 92 & 22.6 \\
\hline & Second Year & 77 & 18.9 \\
\hline & Third Year & 127 & 31.2 \\
\hline & Fourth year and seniors & 66 & 16.2 \\
\hline & Graduate & 45 & 11.1 \\
\hline \multirow[t]{2}{*}{ Presence of Children in the family } & Yes & 258 & 63.4 \\
\hline & No & 149 & 36.6 \\
\hline \multirow[t]{2}{*}{ Live with elders ( $>50$ years) } & Yes & 247 & 60.7 \\
\hline & No & 160 & 39.3 \\
\hline
\end{tabular}

Notes: Others*- Widowed, Separate, in relationship or divorced, others**- Relatives, and Friends.

\section{Knowledge About COVID-19 Vaccination}

This study reported that about $57.5 \%$ (95\% CI: 52.5-62.3\%) of the study participants had poor knowledge regarding COVID-19 disease. More than half (53\%) of the study participants had heard of COVID-19 disease at first from social media. From all the WHO-recommended preventive protocols, most $(80.6 \%),(81.8 \%)$, and $(74.2 \%)$ of the study participants practiced hand washing, used antibiotics, and wore face masks consecutively. Most (69\%) of the study participants knew that only AstraZeneca was given in Ethiopia (Table 2).

\section{Perceptions About COVID-19 Vaccination}

Less than half (43\%) of the study participants were afraid the first time they heard about COVID-19 disease. Less than half (44.2\%) of the study participants perceived the importance of taking COVID-19 vaccination. Most (64\%) of the study participants perceived that they would not get infected with COVID-19 (Table 3).

\section{COVID-19 Vaccine Acceptance}

The level of COVID-19 vaccine acceptance was 39.8\% (95\% CI: 35.0-44.7\%). A quarter (25\%) of the study participants thought it was the best preventive mechanism to prevent COVID-19. One-tenth (11\%) of the study participants did not want to take the vaccine, worrying about the possible side effects (Table 4). 
Table 2 Knowledge of the Study Participants About COVID-19 Vaccination in Selected Colleges of Addis Ababa, Ethiopia, May, 202I

\begin{tabular}{|c|c|c|c|}
\hline Questions & Categories & Frequency & $\%$ \\
\hline \multirow[t]{4}{*}{ Heard COVID-19 diseases at first from } & Social media & 215 & 52.8 \\
\hline & News & 97 & 23.8 \\
\hline & Books/Journals & 3 & 0.7 \\
\hline & TV/Radio & 92 & 22.6 \\
\hline \multirow[t]{3}{*}{ Do you say you have enough Knowledge about COVID-I9 disease? } & Yes & 264 & 64.9 \\
\hline & I know some & 134 & 32.9 \\
\hline & I do not know & 9 & 2.2 \\
\hline \multirow[t]{4}{*}{ What caused COVID-19 disease? } & Fungus & 4 & 1.0 \\
\hline & Bacteria & 5 & 1.2 \\
\hline & Virus & 385 & 94.6 \\
\hline & Others* & 13 & 3.2 \\
\hline \multirow[t]{6}{*}{ Symptoms of COVID-19 } & Cough & 288 & 70.8 \\
\hline & Sneezing & 187 & 45.9 \\
\hline & Fever & 246 & 60.4 \\
\hline & Shortness of breath & 289 & 71.0 \\
\hline & Smell/test Loss & 176 & 43.2 \\
\hline & Diarrhea & 79 & 19.4 \\
\hline A sick person can transmit COVID-19 disease & True & 354 & 87.0 \\
\hline Asymptomatic person can transmit COVID-19 disease & True & 183 & 45.0 \\
\hline Elderly people are the most susceptible groups for COVID-19 & True & 320 & 78.6 \\
\hline Children are the most susceptible groups for COVID-19 & True & 95 & 23.3 \\
\hline Disabled people are most susceptible groups for COVID-19 & True & 47 & 11.5 \\
\hline Chronically ill people are susceptible groups for COVID-19 & True & 215 & 52.8 \\
\hline Health workers are the most susceptible groups for COVID-19 & True & 219 & 53.8 \\
\hline Pneumonia is the common complications of COVID-19 & True & 186 & 45.7 \\
\hline Death is the common complications of coronavirus disease & True & 305 & 74.9 \\
\hline \multirow[t]{8}{*}{ WHO Recommended preventive methods } & Hand washing & 328 & 80.6 \\
\hline & Alcohol rub & 243 & 59.7 \\
\hline & Face mask & 302 & 74.2 \\
\hline & Quarantine & 184 & 45.2 \\
\hline & Antibiotics & 74 & 18.2 \\
\hline & Vaccination & 193 & 47.4 \\
\hline & Balanced diet & 163 & 40.0 \\
\hline & Avoiding crowded places & 199 & 48.9 \\
\hline Have you heard about COVID-19 vaccination? & Yes & 379 & 93.1 \\
\hline \multirow[t]{3}{*}{ The COVID-19 vaccination type currently given in Ethiopia? } & AstraZeneca & 282 & 69.3 \\
\hline & Novavax & 114 & 28.0 \\
\hline & Moderna & 11 & 2.7 \\
\hline
\end{tabular}

Note: Others*- protozoa, evil spirit.

\section{Predictors of COVID-19 Vaccine Acceptance}

The bivariate logistic regression identified candidate variables for the multivariate logistic regression, at the p-value of 0.25 set as a cut-off point. Accordingly, nine variables fulfilled the candidacy for the multivariate logistic regression. After-effects of confounders were controlled in multivariate logistic regression, sex, living with an elderly person who was elder than 50 years old, and knowledge about the COVID-19 vaccine was statistically associated with COVID-19 vaccine acceptance. 
Table 3 Attitude About COVID-19 Disease and Vaccination Among Participants in Selected Colleges of Addis Ababa, Ethiopia, May, 2021

\begin{tabular}{|c|c|c|c|}
\hline Questions & Categories & Frequency & $\%$ \\
\hline \multirow[t]{4}{*}{ How did you feel when you first heard about COVID-19 disease? } & Not concerned & 72 & 17.7 \\
\hline & Concerned & 114 & 28.0 \\
\hline & Afraid & 175 & 43.0 \\
\hline & Anxious & 46 & 11.3 \\
\hline \multirow[t]{3}{*}{ Do you say you have been protecting yourself from COVID-19 disease? } & Yes absolutely & 162 & 39.8 \\
\hline & Medium & 206 & 50.6 \\
\hline & Not really & 39 & 9.6 \\
\hline \multirow[t]{3}{*}{ What do you think about COVID-19 vaccination? } & It is very important for prevention & 180 & 44.2 \\
\hline & I do not know much about it & 173 & 42.5 \\
\hline & I do not really care about it & 54 & 13.3 \\
\hline \multirow[t]{2}{*}{ Do you think you will get infected in the future? } & Yes & 146 & 35.9 \\
\hline & No & 261 & 64.1 \\
\hline
\end{tabular}

The odds of vaccine acceptance was $53.7 \%$ higher among male participants as compared to the females (AOR: 0.463 , $95 \%$ CI: $0.284-0.755, P<0.001)$. The odds of having had vaccine acceptance was 2.295 times higher among participants who lived with under-five years old children (AOR: 2.295; 95CI:1.416-3.721, $P<0.05$ ) and was 1.609 times higher among participants who lived with an elderly person (AOR: 1.609, 95\% CI: 1.016-2.548, $P<0.05$ ). Similarly, the odds of vaccine acceptance was two folds higher among those participants with poor knowledge of COVID-19 compared to those with good knowledge (AOR: 2.187, 95\% CI: 1.391-3.438, $P<0.001$ ) (Table 5).

\section{Discussions}

In this study, the level of vaccine acceptance was $39.8 \%$, which was consistent with the findings from $37.3 \%$ in Uganda, ${ }^{27} 37.4 \%$ in Jordan, ${ }^{28} 47 \%$ in Bangladesh ${ }^{30}$ and $47 \%$ in France. ${ }^{31}$

The current finding was lower than the reports of $54.8 \%$ in Russia, ${ }^{13} 88.6 \%$ in China, ${ }^{13} 64.7 \%$ in Saudi Arabia, ${ }^{32} 67 \%$ in Indonesia, ${ }^{11} 75 \%$ in US $^{24}$ and $83 \%$ in Denmark. ${ }^{31}$ Such variations might be attributed to the variations in the type of vaccine across the different countries and perception differences across the communities. Thus, the lower acceptance level in Ethiopia might be due to a limited option was available at the time of the investigation.

The level of vaccine acceptance in this study was higher than the finding from Republic of Congo that was $27.7 \%{ }^{33}$ This variation might be linked to differences in study participant type across the studies.

In this study, being a male had a higher level of vaccine acceptance. The same was reported by a study from Uganda that being a male was associated with an increased level of vaccine acceptance. ${ }^{27}$ A study from US college students reported that worrying about unknown side effects and unforeseen problems, vaccine cynicism, under evaluation for safety and political conservativeness to be predictors of vaccine hesitancy. ${ }^{34}$

In this study, the level of vaccine acceptance was higher among participants who lived with the elderly and children of under-five years old. This was supported by another study. ${ }^{35}$

The likelihood of vaccine acceptance was two folds higher among participants with poor knowledge about the COVID-19. Probably, participants with good knowledge of COVID-19 might have fear associated with vaccine type, efficacy, and fear associated with AstraZeneca. However, source of the information matters, participants with good knowledge had a higher tendency to vaccine acceptance. ${ }^{36,37}$

\section{Conclusion and Recommendation}

The level of vaccine acceptance among college students in Ethiopia was lower than necessary to achieve herd immunity. Sex, living with under-five children and elderly, knowledge were predictors of vaccine acceptance in the study settings. 
Table 4 COVID-I 9 Vaccination Acceptance of Participants in Selected Medical Colleges of Addis Ababa, Ethiopia, May, 2021

\begin{tabular}{|c|c|c|c|}
\hline Questions & Categories & Frequency & $\%$ \\
\hline \multirow[t]{3}{*}{ Willing to take the COVID-19 vaccination } & Yes & 162 & 39.8 \\
\hline & I do not know & 78 & 19.2 \\
\hline & No & 167 & 41.0 \\
\hline \multirow[t]{7}{*}{ Reasons for wanting to take COVID-19 vaccination } & It is best preventive mechanism & 100 & 24.6 \\
\hline & I am afraid that I might get infected & 33 & 8.1 \\
\hline & $\begin{array}{l}\text { I am afraid for the children in my } \\
\text { home }\end{array}$ & 7 & 1.7 \\
\hline & $\begin{array}{l}\text { I am afraid that I might transmit the } \\
\text { virus to elderly people at home }\end{array}$ & 16 & 3.9 \\
\hline & $\begin{array}{l}\text { It is WHO recommended } \\
\text { preventive }\end{array}$ & 3 & 0.7 \\
\hline & I saw famous people taking it & 2 & 0.5 \\
\hline & $\begin{array}{l}\text { Someone I know had taken the } \\
\text { vaccine }\end{array}$ & 2 & 0.5 \\
\hline \multirow[t]{11}{*}{ Reasons for not wanting to take COVID-19 vaccination } & Afraid of the possible side effects & 47 & 11.5 \\
\hline & Believe it is biological weapon & 30 & 7.4 \\
\hline & Have doubt about the vaccine & 18 & 4.4 \\
\hline & $\begin{array}{l}\text { Unreliable due to short time for } \\
\text { development }\end{array}$ & 30 & 7.4 \\
\hline & Do not have enough information & 23 & 5.7 \\
\hline & Prefer other ways of protection & 9 & 2.2 \\
\hline & The vaccine itself can cause & 6 & 1.5 \\
\hline & COVID-19 disease & & \\
\hline & Its ineffective & I & 0.2 \\
\hline & $\begin{array}{l}\text { COVID-19 is overrated, no vaccine } \\
\text { needed }\end{array}$ & 3 & 0.7 \\
\hline & Others* & I & 0.2 \\
\hline \multirow{3}{*}{$\begin{array}{l}\text { If a doctor or the government recommended you to take the vaccine, } \\
\text { would you take it? }\end{array}$} & Yes & 30 & 7.4 \\
\hline & No & 122 & 30.0 \\
\hline & I do not know & 16 & 3.9 \\
\hline \multirow{3}{*}{$\begin{array}{l}\text { If it was other vaccine like a vaccination like Human Papilloma Virus } \\
\text { (for women), or a vaccination for influenza, would you take it }\end{array}$} & Yes & 90 & 22.1 \\
\hline & No & 53 & 13.0 \\
\hline & I do not know & 24 & 5.9 \\
\hline \multirow[t]{3}{*}{ Have you been infected with COVID-19 virus? } & Yes & 42 & 10.3 \\
\hline & I do not know & 135 & 33.2 \\
\hline & No & 230 & 56.5 \\
\hline \multirow[t]{2}{*}{ Have you ever been tested for COVID-19? } & Yes & 106 & 26.0 \\
\hline & No & 301 & 74.0 \\
\hline \multirow{3}{*}{$\begin{array}{l}\text { Do you know anyone who died, been sick and had been admitted to } \\
\text { hospital or anyone who had been in quarantine before? }\end{array}$} & Yes & 281 & 69.0 \\
\hline & No & 107 & 26.3 \\
\hline & Nothing to say & 19 & 4.7 \\
\hline
\end{tabular}

Note: Others*- pregnancy, heart disease.

Policymakers, stakeholders, and concerned bodies were recommended to work on the identified predictors of COVID-19 vaccine acceptance.

\section{Limitation of the Study}

The study was a cross-sectional study, which had a nature of point observation and difficult to establish the temporal association between variables. The other limitation was difficulty of inferring to the community at large, as it was an institution-based study. 
Table 5 Predictors of COVID-I 9 Vaccine Acceptance of in Selected Colleges Students of Addis Ababa, Ethiopia 202I

\begin{tabular}{|c|c|c|c|c|c|}
\hline \multirow[t]{2}{*}{ Characteristics } & \multirow[t]{2}{*}{ Categories } & \multicolumn{2}{|c|}{$\begin{array}{l}\text { Vaccine } \\
\text { Acceptance } \\
\text { status }\end{array}$} & \multirow[t]{2}{*}{ COR $(95 \% \mathrm{Cl})$} & \multirow[t]{2}{*}{ AOR (95\% Cl) } \\
\hline & & Yes & No & & \\
\hline \multirow[t]{4}{*}{ Age } & 20 or less & 46 & 78 & I & I \\
\hline & $21-23$ & 79 & 138 & $1.030(0.652-1.628)$ & $1.113(0.636-1.947)$ \\
\hline & $24-26$ & 17 & 22 & $0.763(0.368-1.584)$ & $1.230(0.473-3.198)$ \\
\hline & 27 and older & 20 & 7 & $0.206(0.081-0.526)^{* *}$ & $0.465(0.133-1.621)$ \\
\hline \multirow[t]{2}{*}{ Sex } & Female & 91 & 186 & 1.00 & 1.00 \\
\hline & Male & 71 & 59 & $0.407(0.265-0.623)^{* *}$ & $0.463(0.284-0.755)^{* *}$ \\
\hline \multirow[t]{4}{*}{ Religion } & Protestant & 28 & 39 & I & 1 \\
\hline & Orthodox & 95 & 170 & $1.285(0.744-2.219)$ & $1.033(0.559-1.908)$ \\
\hline & Muslim & 26 & 31 & $0.856(0.420-1.745)$ & $0.784(0.361-1.704))$ \\
\hline & Catholic & 13 & 5 & $0.276(0.088-0.863)$ & $0.326(0.92-1.160)$ \\
\hline \multirow[t]{3}{*}{ Marital Status } & Single & $|3|$ & 206 & I & I \\
\hline & Married & 25 & 23 & $0.585(0.319-1.074)$ & $1.030(0.472-2.246))$ \\
\hline & Others & 6 & 16 & $1.696(0.647-4.444)$ & I.648(0.587-4.627) \\
\hline \multirow[t]{3}{*}{ Source of income } & Family & 129 & 214 & I & I \\
\hline & Work & 22 & 22 & $0.603(0.321-1.132)$ & $0.829(0.368-1.865)$ \\
\hline & Other & II & 9 & $0.493(0.199-1.222)$ & $0.676(0.240-1.906)$ \\
\hline \multirow[t]{5}{*}{ Academic year } & Freshman & 35 & 57 & 1 & 1 \\
\hline & Second year & 25 & 52 & $1.277(0.676-2.413)$ & $1.061(0.529-2.126)$ \\
\hline & Third & 53 & 74 & $0.857(0.495-1.485)$ & $0.603(0.3 \mid 4-1.155)$ \\
\hline & Senior & 26 & 40 & $0.945(0.494-1.207)$ & $0.947(0.423-0.2 .118)$ \\
\hline & Graduate & 23 & 22 & $0.587(0.286-1.207)$ & $0.563(0.224-1.408)$ \\
\hline \multirow[t]{2}{*}{ Are there children in your home } & Yes & 108 & 150 & I & I \\
\hline & No & 54 & 95 & $1.267(0.836-1.919)$ & $2.295(1.416-3.721))^{*}$ \\
\hline \multirow[t]{2}{*}{ Is there elderly person who is $>50$ of age in your home } & Yes & 97 & 150 & I & 1 \\
\hline & No & 65 & 95 & $0.945(0.630-1.418)$ & $1.753(1.095-2.807)^{*}$ \\
\hline \multirow[t]{2}{*}{ Knowledge about COVID-19 Vaccination } & Poor knowledge & 112 & 122 & I & I \\
\hline & Good knowledge & 50 & 123 & $2.258(I .488-3.427)^{* *}$ & $2.187(1.391-3.438)^{* *}$ \\
\hline
\end{tabular}

Notes: ${ }^{*} p<0.05,{ }^{*} *_{p}<0.001$.

\section{Abbreviations}

AOR, adjusted odds ratio; COR, crude odds ratio; COVID-19, coronavirus disease 2019; WHO, World Health Organization. 


\section{Data Sharing Statement}

A finding of this study was generated from the data collected and analyzed on the basis of stated methods and materials, hence all data were already available in the manuscript.

\section{Ethics Approval and Consent to Participate}

The study protocol was performed in accordance with the ethical principle. Ethical approval was obtained from ethics review Committee of Universal Medical and Business College. The ethics approval was given in accordance with the Declaration of Helsinki. The data collectors obtained written informed consent from all participants.

\section{Consent for Publication}

Consent for publication of the manuscript was not applicable due to the fact that there were no participant's individual data videos or images.

\section{Acknowledgments}

The authors thank study participants for their willingness in taking part in the study.

\section{Author Contributions}

All authors contributed to data analysis, drafting or revising the article, have agreed on the journal to which the article was submitted, gave final approval of the version to be published, and agreed to be accountable for all aspects of the work.

\section{Funding}

The authors received no specific funding for this work.

\section{Disclosure}

The authors declare no conflicts of interest for this work.

\section{References}

1. McKibbin W, Fernando R. The economic impact of COVID-19. In: Economics in the Time of COVID-19. 2020:45.

2. Yu Z, Razzaq A, Rehman A, Shah A, Jameel K, Mor RS. Disruption in global supply chain and socio-economic shocks: a lesson from COVID-19 for sustainable production and consumption. Oper Manag Res. 2021;1-16. doi:10.1007/s12063-021-00179-y

3. Das K. Impact of COVID-19 pandemic into solar energy generation sector. Available at SSRN 3580341; 2020.

4. Mofijur M, Fattah IR, Alam MA, et al. Impact of COVID-19 on the social, economic, environmental and energy domains: lessons learnt from a global pandemic. Sustain Prod Consum. 2020;26:343-359. doi:10.1016/j.spc.2020.10.016

5. Qiao S, Friedman DB, Tam CC, Zeng C, Li X. Vaccine acceptance among college students in South Carolina: do information sources and trust in information make a difference? MedRxiv. 2020. doi:10.1101/2020.12.02.20242982

6. Elmezayen AD, Al-Obaidi A, Şahin AT, Yelekçi K. Drug repurposing for coronavirus (COVID-19): in silico screening of known drugs against coronavirus 3CL hydrolase and protease enzymes. J Biomol Struct Dyn. 2021;39(8):2980-2992. doi:10.1080/07391102.2020.1758791

7. Agarwal A, Mukherjee A, Kumar G, Chatterjee P, Bhatnagar T, Malhotra P. Convalescent plasma in the management of moderate covid-19 in adults in India: open label phase II multicentre randomised controlled trial (PLACID Trial). BMJ. 2020;371:m3939.

8. Consortium WST. Repurposed antiviral drugs for COVID-19-interim WHO SOLIDARITY trial results. N Engl J Med. 2021;384(6):497-511.

9. Looi M-K. Covid-19: is a second wave hitting Europe? BMJ. 2020;371:m4113.

10. Wang J, Jing R, Lai X, et al. Acceptance of COVID-19 vaccination during the COVID-19 pandemic in China. Vaccines. 2020;8(3):482. doi:10.3390/vaccines8030482

11. Harapan H, Wagner AL, Yufika A, et al. Acceptance of a COVID-19 vaccine in Southeast Asia: a cross-sectional study in Indonesia. Front Public Health. 2020;8. doi:10.3389/fpubh.2020.00381

12. Saitoh A, Saitoh A, Katsuta T, et al. Effect of a vaccine information statement (VIS) on immunization status and parental knowledge, attitudes, and beliefs regarding infant immunization in Japan. Vaccine. 2020;38(50):8049-8054. doi:10.1016/j.vaccine.2020.10.049

13. Lazarus JV, Ratzan SC, Palayew A, et al. A global survey of potential acceptance of a COVID-19 vaccine. Nat Med. 2021;27(2):225-228. doi:10.1038/s41591-020-1124-9

14. Feleszko W, Lewulis P, Czarnecki A, Waszkiewicz P. Flattening the curve of COVID-19 vaccine rejection-A global overview. Available at SSRN; 2020.

15. Dubé E, Gagnon D, MacDonald N, Bocquier A, Peretti-Watel P, Verger P. Underlying factors impacting vaccine hesitancy in high income countries: a review of qualitative studies. Expert Rev Vaccines. 2018;17(11):989-1004. doi:10.1080/14760584.2018.1541406 
16. Adamu AA, Essoh T-A, Adeyanju GC, et al. Drivers of hesitancy towards recommended childhood vaccines in African settings: a scoping review of literature from Kenya, Malawi and Ethiopia. Expert Rev Vaccines. 2021;20:1-11.

17. Peretti-Watel P, Ward JK, Vergelys C, Bocquier A, Raude J, Verger P. 'I think I made the right decision... I hope I'm not wrong'. Vaccine hesitancy, commitment and trust among parents of young children. Sociol Health Illn. 2019;41(6):1192-1206.

18. Freed GL, Clark SJ, Butchart AT, Singer DC, Davis MM. Sources and perceived credibility of vaccine-safety information for parents. Pediatrics. 2011;127(Supplement 1):S107-S12. doi:10.1542/peds.2010-1722P

19. Van Scoy LJ, Miller EL, Snyder B, et al. Knowledge, perceptions, and preferred information sources related to COVID-19 among central Pennsylvania adults early in the pandemic: a mixed methods cross-sectional survey. Ann Fam Med. 2021;19(4):293-301. doi:10.1370/afm.2674

20. Lin D, Friedman DB, Qiao S, Tam CC, Li X, Li X. Information uncertainty: a correlate for acute stress disorder during the COVID-19 outbreak in China. BMC Public Health. 2020;20(1):1-9. doi:10.1186/s12889-020-09952-3

21. Roy A, Singh AK, Mishra S, Chinnadurai A, Mitra A, Bakshi O. Mental health implications of COVID-19 pandemic and its response in India. Int J Soc Psychiatry. 2020;67(5):587-600. doi:10.1177/0020764020950769

22. Paluszek MM, Landry CA, Taylor S, Asmundson GJ. The psychological sequelae of the COVID-19 pandemic: psychological processes, current research ventures, and preparing for a postpandemic world. Behav Ther. 2020;43:158-163.

23. Van Scoy LJ, Snyder B, Miller EL, et al. Public anxiety and distrust due to perceived politicization and media sensationalism during early COVID-19 media messaging. J Commun Healthc. 2021;14(3):193-205. doi:10.1080/17538068.2021.1953934

24. Lennon RP, Small ML, Smith RA, et al. Unique predictors of intended uptake of a COVID-19 vaccine in adults living in a rural college town in the United States. Am J Health Promot. 2022;36(1):180-184. doi:10.1177/08901171211026132

25. Barello S, Nania T, Dellafiore F, Graffigna G, Caruso R. 'Vaccine hesitancy'among university students in Italy during the COVID-19 pandemic. Eur J Epidemiol. 2020;35(8):781-783. doi:10.1007/s10654-020-00670-Z

26. Lucia VC, Kelekar A, Afonso NM. COVID-19 vaccine hesitancy among medical students. J Public Health. 2020. doi:10.1093/pubmed/fdaa230

27. Kanyike AM, Olum R, Kajjimu J, et al. Acceptance of the coronavirus disease-2019 vaccine among medical students in Uganda. Trop Med Health. 2021;49(1):1-11. doi:10.1186/s41182-021-00331-1

28. El-Elimat T, AbuAlSamen MM, Almomani BA, Al-Sawalha NA, Alali FQ. Acceptance and attitudes toward COVID-19 vaccines: a cross-sectional study from Jordan. PLoS One. 2021;16(4):e0250555. doi:10.1371/journal.pone.0250555

29. Brewer NT, DeFrank JT, Gilkey MB. Anticipated regret and health behavior: a meta-analysis. Health Psychol. 2016;35(11):1264. doi:10.1037/ hea0000294

30. Abedin M, Islam MA, Rahman FN, et al. Willingness to vaccinate against COVID-19 among Bangladeshi adults: understanding the strategies to optimize vaccination coverage. PLoS One. 2021;16(4):e0250495. doi:10.1371/journal.pone.0250495

31. Lindholt MF, Jørgensen F, Bor A, Petersen MB. Public acceptance of COVID-19 vaccines: cross-national evidence on levels and individual-level predictors using observational data. BMJ Open. 2021;11(6):e048172. doi:10.1136/bmjopen-2020-048172

32. Al-Mohaithef M, Padhi BK. Determinants of COVID-19 vaccine acceptance in Saudi Arabia: a web-based national survey. J Multidiscip Healthc. 2020;13:1657. doi:10.2147/JMDH.S276771

33. Nzaji MK, Ngombe LK, Mwamba GN, et al. Acceptability of vaccination against COVID-19 among healthcare workers in the Democratic Republic of the Congo. Pragmat Obs Res. 2020;11:103. doi:10.2147/POR.S271096

34. Small ML, Lennon R, Dziak J, Smith RA, Sommerville G, Bharti N. College Students' COVID-19 Vaccine Beliefs and Intentions: implications for interventions. medRxiv. 2021. doi:10.1101/2021.05.28.21258008

35. Kerr JR, Schneider CR, Recchia G, et al. Predictors of COVID-19 vaccine acceptance across time and countries. MedRxiv. 2020. doi:10.1101/ 2020.12.09.20246439

36. Abebe H, Shitu S, Mose A. Understanding of COVID-19 vaccine knowledge, attitude, acceptance, and determinates of COVID-19 vaccine acceptance among adult population in Ethiopia. Infect Drug Resist. 2021;14:2015. doi:10.2147/IDR.S312116

37. Sakya SM, Scoy LJV, Garman JC, et al. The impact of COVID-19-related changes in media consumption on public knowledge: results of a cross-sectional survey of Pennsylvania adults. Curr Med Res Opin. 2021;37(6):911-915. doi:10.1080/03007995.2021.1901679

\author{
Patient Preference and Adherence
}

Dovepress

\title{
Publish your work in this journal
}

Patient Preference and Adherence is an international, peer-reviewed, open access journal that focusing on the growing importance of patient preference and adherence throughout the therapeutic continuum. Patient satisfaction, acceptability, quality of life, compliance, persistence and their role in developing new therapeutic modalities and compounds to optimize clinical outcomes for existing disease states are major areas of interest for the journal. This journal has been accepted for indexing on PubMed Central. The manuscript management system is completely online and includes a very quick and fair peer-review system, which is all easy to use. Visit http://www.dovepress.com/testimonials.php to read real quotes from published authors.

Submit your manuscript here: https://www.dovepress.com/patient-preference-and-adherence-journal 